\title{
Validitas dan Praktikalitas Rencana Pembelajaran Semester (RPS) Terintegrasi Research Based Learning
}

\author{
Umil Muhsinin $^{1}$, Kiki Fatmawati ${ }^{2}$ \\ ${ }^{1,2}$ Program Studi PGMI UIN STS Jambi, Jl. Jambi-Ma. Bulian KM. 16 \\ Correspondence e-mail: umilmuhsinin@uinjambi.ac.id
}

\begin{abstract}
Abstrak. Hasil riset menunjukkan bahwa mahasiswa kebanyakan kesulitan untuk menyelesaikan studinya. Adapun salah satu penyebabnya adalah kurangnya kemampuan menulis karya ilmiah, Lemahnya metodologi penelitian dan kurangnya keterlibatan mahasiswa dalam penelitian dosen. Oleh karena itu dilakukan penelitian pengembangan rencana pembelajaran semester terintegrasi research based learning Penelitian ini bertujuan untuk menghasilkan RPS yang valid dan praktis. Model yang digunakan dalam pengembangan ini adalah model 4-D. Penelitian dilakukan di Semester V jurusan PGMI FTK UIN STS Jambi. Teknik pengumpulan data menggunakan angket yang terdiri dari lembar validasi ahli, lembar respon dosen terhadap RPS, serta lembar keterlaksanaan RPS. Hasil penelitian menunjukkan bahwa perangkat pembelajaran yang dikembangkan telah memenuhi kriteria valid dan praktis. Hal ini dapat dilihat berdasarkan hasil validasi RPS oleh validator ahli dan praktisi pendidikan yang telah dilaksanakan, yang dikembangkan memperoleh skor rat-rata yaitu 3,9 dengan kategori sangat valid. Praktikalitas RPS diketahui dari hasil pengamatan keterlaksanaan pembelajaran dengan rata-rata 93,3\% kategori sangat praktis, angket respons dosen rata-rata yaitu $90 \%$ dengan kategori praktis.
\end{abstract}

Kata kunci: Praktikalitas; RPS; Research Based Learning; Validitas

\begin{abstract}
The research results show that most students find it difficult to complete their studies. One reason is the lack of ability to write scientific papers, the weakness of research methodology and the lack of student involvement in lecturer research. Therefore, research on the development of integrated semester learning plans is based on research. This research aims to produce a valid and practical RPS. The model used in this development is the 4-D model. The study was conducted in Semester V, majoring in PGMI FTK UIN STS Jambi. Data collection techniques used a questionnaire consisting of an expert validation sheet, a lecturer response sheet to the RPS, and a RPS implementation sheet. The results showed that the learning tools developed had met the valid and practical criteria. This can be seen based on the results of the validation of the RPS by expert validators and education practitioners who have been implemented, which developed an average score of 3.9 with a very valid category. The practicality of RPS is known from observations of the implementation of learning with an average of $93.3 \%$ the category is very practical, the questionnaire responses of lecturers on average is $90 \%$ with the practical category.
\end{abstract}

Keywords: Practicality; RPS; Research Based Learning; Validity

\section{PENDAHULUAN}

Ketercapaian tuntutan KPT terwujud jika kegiatan perkuliahan dilaksanakan secara optimal, artinya kegiatan perkuliahan yang melibatkan dosen dan mahasiswa harus dilakukan secara baik dan seideal mungkin. Dosen dan mahasiswa harus aktif dalam perkuliahan. Kegiatan perkuliahan harus terpusat pada mahasiswa (student centered). Namun pada kenyataannya pada saat berlangsungnya kegiatan kuliah nampak sebagian besar mahasiswa yang mengikuti perkuliahan sulit memahami pentingnya pembelajaran yang berlangsung. Hal ini terbukti dari pertanyaanpertnyaan yang diajukan oleh dosen, tidak ada satupun mahasiswa yang berani menjawab pertanyaan tersebut dan sebagian dari mahasiswa bersikap pasif dengan menunggu penjelasan dari dosen. Terlihat bahwa mahasiswa lebih senang dan terbiasa mendengarkan ceramah dosen daripada harus aktif dalam mengikuti perkuliahan. Selanjutnya Hasil riset menunjukkan bahwa mahasiswa kebanyakan kesulitan untuk menyelesaikan studinya. Adapun salah satu penyebabnya adalah kurangnya kemampuan menulis karya ilmiah, Lemahnya metodologi penelitian dan kurangnya keterlibatan mahasiswa dalam penelitian dosen.

Perencanaan yang akan dilakukan dalam proses pembelajaran disusun untuk setiap mata kuliah dan disajikan dalam Rencana Pembelajaran Semester (RPS). RPS ditetapkan dan dikembangkan oleh dosen secara mandiri dan/atau bersama dalam kelompok keahlian suatu bidang ilmu pengetahuan dan/atau teknologi dalam program studi. Dalam penyelenggaran dan pengelolaan pendidikan Diploma maupun Sarjana Program studi wajib menyusun RPS dalam setiap mata kuliah. Hasil analisis RPS yang selama ini digunakan dijurusan PGMI adalah dalam RPS belum ditemukan model-model pembelajaran yang bervariarif dan mendukung nilai riset, dosen masih menggunakan model pembelajaran ceramah dan diskusi.

Research Based Learning atau Pembelajaran berbasis riset adalah model pembelajaran yang bersifat otentik dengan sudut pandang formulasi permasalahan, penyelesaian masalah, dan mengkomunikasi manfaat penelitian (Kartika Cristy, 2014). Oleh karena itu pembelajaran berbasis riset, dinilai sangat tepat 
diterapkan dalam pembelajaran yang berpusat pada mahasiswa, yaitu pembelajaran yang memenuhi karakteristik standar proses seperti sifat interaktif, holistik, integratif, saintifik, kontekstual, tematik, efektif, kolaboratif dan berpusat pada mahasiswa. Sehingga model pembelajaran ini sangat efektif untuk diterapkan karena model pembelajaran berbasis riset pada dasarnya lebih mendorong mahasiswa untuk aktif dalam memperoleh pengetahuan. Dengan banyaknnya aktivitas yang dilakukan oleh mahasiswa, diharapkan dapat meningkatkan aktivitas mahasiswa dalam belajar.

Kehandalan implementasi praktis pembelajaran berbasis riset ditunjukkan oleh keberhasilannya dalam ujicoba-ujicoba pembelajaran. Metodologi penelitian yang mendukung upaya ini adalah metode penelitian pengembangan. Istilah penelitian pengembangan merupakan penyederhanaan dari istilah penelitian dan pengembangan atau Research and Development (R\&D). Menurut Setyosari (2010), dikatakan sebagai penelitian pengembangan karena penelitian ini sering dianggap sebagai pengembangan berbasis penelitian atau "Research Based Development" sehingga biasa disingkat menjadi penelitian pengembangan. tiga syarat utama yang harus diperhatikan dalam penelitian pengembangan, yaitu: validitas, praktikalitas. Kevalidan artinya keabsahan atau kelayakan suatu produk. Uji kevalidan produk dalam penelitian pengembangan berguna untuk melihat kelayakan suatu produk yang akan digunakan dalam proses pembelajaran. sedangkan Praktikalitas atau bersifat praktis, artinya mudah dan senang memakainya. Praktikalitas berkaitan dengan keterpakaian produk dalam penelitian pengembangan oleh pengguna produk tersebut. produk dikatakan praktis jika pengguna mudah menggunakan produk tersebut dalam proses pembelajaran yang logis dan berkesinambungan tanpa banyak masalah.

Penelitian tentang Research Based Learning sudah banyak dilakukan begitu pula pengembangan perangkat pembelajaran berupa silabus, RPS, instrument penilaian. Artikel penelitian yang dilakukan oleh Lioni Anka Monalisa dkk dari Jurusan Pendidikan Matematika FKIP Universitas Jember, yang dilaporkan pada tahun 2016. Penelitian in berjudul Pengembangan Perangkat Pembelajaran Mata Kuliah Teori Bilangan Program Studi Pendidikan Matematika Berdasarkan Kurikulum Kerangka Kualifikasi Nasional Indonesia (KKNI). Selanjutnya Penelitian berjudul Pembelajaran Berbasis Riset Dengan Pendekatan Saintifik Dalam Peningkatkan Keterampilan Proses IPA Bagi Siswa SD, yang ditulis oleh Kartika Chrysti S. Hanya saja penelitian-penelitian yang telah dilakukan tidak ada pengintegrasian anatara RPS dan ResearchBased Learning. Oleh karena itu penelitian ini akan menyempurnakan kekurangan penelitian sebelumnya. Penelitian pengembangan RPS terintegrasi ResearchBased Learning diharapkan dapat membantu dosen dalam melaksanakan proses perkuliahan dan diharapkan dapat meningkatkan pemahaman dan ketertarikan mahasiswa terhadap proses perkuliahan yang kemudian dapat mendorong mahasiswa untuk meningkatkan hasil belajar.

\section{METODE}

Jenis penelitian yang digunakan adalah penelitian pengembangan yang lebih kita kenal dengan istilah Research \& Development (R\&D). Menurut Gray, dkk (2019) "Research and Development $(R \& D)$ is the process of researching consumer needs and then developing products to fulfill those needs". Selanjutnya Sugiyono (2011) mengemukakan bahwa "penelitian pengembangan adalah penelitian yang menghasilkan produk tertentu dan menguji kepraktisan produk tersebut".

Penelitian ini dilaksanakan untuk mengembangkan RPS terintegrasi Research Based Learning. Penelitian ini menggunakan model 4D (four$D$ models). Menurut Thiangarajan (dalam Trianto) model 4D (four-D models) terdiri dari sebagai berikut: (1) pendefinisian(define), (2)perancangan (design), (3)pengembangan (develop), dan (4) penyebaran (disseminate) (Trianto, 2011:184). Penelitian ini hanya sampai pada tahap pengembangan. Meskipun hanya sampai pada tahap pengembangan, perangkat pembelajaran ini sudah mencakup prinsip penelitian pengembangan. Menurut Mulyatiningsih (2012) inti dari penelitian pengembangan adalah adanya validasi dan revisi terhadap perangkat pembelajaran yang dikembangkan.

\section{HASIL DAN PEMBAHASAN}

Setelah penelitian tentang pengembangan rencana pembelajaran semester terintegrasi research based learning dengan model pengembangan 4-D, diperoleh hasil penelitian sebagai berikut:

\section{Tahap Pendefenisian (Define)}

Pada tahap pendefenisian dilakukan analisis pada beberapa aspek, yang meliputi: analisis RPS, analisis kebutuhan dan analisis karakteristik mahasiswa. Untuk lebih jelasnya, dipaparkan hasil analisis tersebut sebagai berikut:

\section{Analisis RPS}

Pada tahap analisis ini dilakukan analisis terhadap RPS yang berlaku. Pada penelitian ini, RPS yang dianalisis disesuaikan pada kurikulum Kerangka Kualifikasi Nasional Indonesia (KKNI). Analisis RPS bertujuan untuk mengetahui dan menelaah sejauh mana kompetensi yang harus dimiliki oleh mahasiswa berdasarkan capaian pembelajaran kelulusan yang dituntut oleh kurikulum KKNI dalam menyelenggarakan pembelajaran di prodi PGMI. Selain itu, untuk mengetahui cakupan materi/bahan kajian, proses dan 
capaian pembelajaran yang sesuai sebagai landasan untuk mengembangkan RPS yang diharapkan.

Hasil dari tahapan ini komponen RPS yang digunakan oleh dosen mata kuliah metode penelitian masih belum lengkap, belum ditemukan pengalaman belajar mahasiswa yang diwujudkan dalam deskripsi tugas yang harus dikerjakan oleh mahasiswa selama satu semester dan metode pembelajaran yang digunakan belum bervariasi hanya diiskusi dan ceramah. Seharusnya pada mata kuliah metode penelitia $\mathrm{n}$ ini digunakan metode pembelajaran yang bervariasi yang sesuai dengan tuntutan capaian pembelajaran dari mata kuliah ini adalah menghasilkan produk/proyek proposal penelitian. sebaiknya digunakan metode pembelajaran berbasis proyek dan metode pembelajaran berbasis riset.

Oleh karena itu RPS yang digunakan berbasis pembelajaran riset diharapkan mencapai capaian pembelajaran dan indikator yang telah dibuat

\section{Analisis kebutuhan}

Analisis kebutuhan ini dilakukan setelah menganalis kurikulum KKNI. Analisis kebutuhan dilakukan dengan menganalisis RPS. Kebutuhan ini mencakup RPS yang digunakan dosen selama proses pembelajaran. Penyusunan RPS merupakan bagian dari perencanaan proses pembelajaran. Kondisi di lapangan menunjukkan bahwa sebagian besar dosen kurang mempersiapkan perencanaan pembelajaran dengan baik sehingga berpengaruh dalam pelaksanaan pembelajaran.

Berdasarkan hasil analisis yang peneliti lakukan terhadap RPS masih terdapat ketidakcocokan antara indikator dan capaian pembelajaran yang harus di capai serta metode pembelajaran. capaian pembelajaran yang terdapat dalam RPS hanya menyangkut pada aspek pengetahuan saja, tidak menyangkut pada aspek keterampilan umum dan keterapilan khusus dan sikap yang harus dicapai mahasiswa. Hal demikian berdampak terhadap ketidaktercapaian capaian pembelajaran sebagaimana mestinya. Hal lain yang juga ditemukan yaitu capaian pembelajaran tidak sesuai dengan ruang lingkup. Selanjutnya, dalam proses penilaian diperoleh informasi bahwa penilaian pembelajaran hanya berorientasi pada hasil atau pengetahuan saja. Sedangkan penilaian proses yang termasuk penilaian sikap dan penilaian keterampilan masih sedikit terabaikan. Analisis kebutuhan juga dilakukan dengan mewawancarai beberapa orang mahasiswa PGMI FTK UIN STS Jambi.

Berdasarkan wawancara yang peneliti lakukan, diperoleh informasi bahwa selama ini pembelajaran yang diterima mahasiswa kurang menarik bagi mahasiswa, kegiatan pembelajaran kurang bervariasi, kurang berkaitan dengan hasil-hasil riset di sekitar mahasiswa. Berdasarkan analisis tersebut, terlihat bahwa diperlukan RPS yang dapat mengarahkan siswa untuk aktif. RPS yang digunakan hendaklah disesuaikan dengan karakteristik mahasiswa semester V.

\section{Analisis Karakteristik mahasiswa}

Analisis mahasiswa merupakan telaah terhadap karakteristik siswa. Analisis ini diperlukan sebelum merancang perangkat pembelajaran khususnya RPS. Hal ini sesuai dengan pendapat Uno (2007:27) yang menyatakan mengidentifikasi tingkah laku dan karakteristik siswa sangat perlu dilakukan untuk mengetahui kualitas perseorangan yang dapat dijadikan sebagai petunjuk dalam perencanaan pembelajaran. Analisis ini dijadikan sebagi acuan dasar pengembangan rencana pembelajaran semester terintegrasi research based learning.

Analisis karakteristik mahasiswa dilakukan dengan tujuan agar perangkat pembelajaran berupa RPS yang akan dihasilkan sesuai dengan karakteristik mahasiswa dan pembelajaran dapat berlangsung sesuai dengan capaian pembelajaran yang diharapkan. Berdasarkan hasil wawancara peneliti dengan mahasiswa diperoleh bahwa mahasiswa rata-rata berusia 20- 21 tahun yang berada pada tahap formal operasional period. Hasil analisis mahasiswa ini dapat diketahui bahwa mahasiswa lebih menyukai rancangan pembelajaran yang bisa dan dapat digunakan untuk belajar mandiri, yang juga dapat memberikan kesempatan kepada mahasiswa untuk mengembangkan kemampuannya sendiri dengan cara belajar sendiri ataupun berkelompok. Hasil analisis mahasiswa lainnya diperoleh hasil dalam hal analisis kemampuan dalam belajar. Pada umumnya kemampuan akademik antara mahasiswa berbeda. Hal ini terlihat dari nilai yang diperoleh oleh mahasiswa pada setiap semester.

\section{Tahap Perancangan (Design)}

Berdasarkan analisis RPS, analisis kebutuhan dan analisis karakteristik mahasiswa pada tahap pendefenisian maka dilakukan perancangan rencana pembelajaran semester terintegrasi research based learning untuk mata kuliah metode penelitian. RPS disesuaikan dengan capaian pembelajaran yang ditetapkan pada kurikulum KKNI, kemudian disusun sesuai dengan langkah-langkah pada model pembelajaran berbasis riset. RPS yang dirancang mendorong mahasiswa untuk aktif, mampu menganalisis, mampu berfikir kritis dan mampu bertukar pikiran dalam pembelajaran.

Format dari penyusunan RPS ini ini dimodifikasi menurut Standar Nasional Pendidikan Tinggi (SN Dikti), RPS atau istilah lain, paling sedikit memuat: (a) nama program studi, nama dan kode mata kuliah, semester, sks, nama dosen pengampu; (b) capaian pembelajaran lulusan yang dibebankan pada mata kuliah; (c) kemampuan akhir yang direncanakan pada tiap tahap pembelajaran untuk memenuhi capaian pembelajaran lulusan; (d) bahan kajian yang terkait dengan 
kemampuan yang akan dicapai; (e) metode pembelajaran; (f) waktu yang disediakan untuk mencapai kemampuan pada tiap tahap pembelajaran; $(\mathrm{g})$ pengalaman belajar mahasiswa yang diwujudkan dalam deskripsi tugas yang harus dikerjakan oleh mahasiswa selama satu semester; (h) kriteria, indikator, dan bobot penilaian; dan (i) daftar referensi yang digunakan.

\section{Tahap Pengembangan (Develop)}

Setelah melakukan tahap perancangan, langkah selanjutnya yaitu tahap pengembangan. Tahap pengembangan ini bertujuan untuk menghasilkan Rencana Pembelajaran Semester terintegrasi research based learning yang valid dan praktis, sehingga layak digunakan dalam proses pembelajaran. Tahap pengembangan ini terdiri atas dua tahap, yaitu: validasi RPS dan uji praktikalitas.

\section{Validasi Rencana Pembelajaran Semester (RPS)}

Rencana Pembelajaran Semester (RPS) yang dirancang kemudian divalidasi oleh validator. Validitas diperlukan untuk menguji suatu penelitian. Sudijono, (1995: 93) menyatakan bahwa "kata valid sering diartikan dengan tepat, benar, sahih, absah; jadi kata validitas dapat diartikan dengan ketepatan, kebenaran, keshahihan atau keabsahan". Validitas RPS yang telah dikembangkan dikatakan valid apabila memenuhi kriteria tertentu. Menurut Sugiyono (2007:173) "suatu produk dikatakan valid apabila produk tersebut dapat digunakan untuk mengukur apa yang seharusnya diukur".

Validasi dilakukan oleh tiga orang validator dari perguruan tinggi. Pada kegiatan ini, pakar dan praktisi diminta untuk menilai RPS yang sudah dibuat. Penilaian mencakup identitas, capaian pembelajaran, kemampuan akhir, bahan kajian, Metode pembelajaran, waktu penyusunan kegiatan pembelajaran, kriteria indikator dan bobot penilaian serta daftar referensi. Validator diminta untuk memberikan penilaian serta saran perbaikan dari RPS yang telah dirancang.

Hasil penilaian validator mencakup identitas, capaian pembelajaran, kemampuan akhir, bahan kajian, Metode pembelajaran, waktu penyusunan kegiatan pembelajaran, kriteria indikator dan bobot penilaian serta daftar referensi dengan rata-rata 3,9 termasuk dalam kategori sangat valid.

\section{Data observasi pelakasanaan pembelajaran}

Data observasi pelaksanaan pembelajaran diambil dari lembar observasi keterlaksanaan RPS yang diperoleh observer pada setiap kali pertemuan.

Tabel 1. Rekapitulasi Observasi Keterlaksanaan RPS

\begin{tabular}{|c|c|c|c|c|}
\hline \multirow[b]{2}{*}{ Pembelajaran } & \multicolumn{2}{|c|}{ Persentase Penilaian Observer } & \multirow{2}{*}{$\begin{array}{c}\text { Rata-rata } \\
\text { Total }\end{array}$} & \multirow[t]{2}{*}{ Kategori } \\
\hline & 01 & $\mathbf{0 2}$ & & \\
\hline Pembelajaran 1 (Senin) & 3,6 & 3,5 & 3,55 & Praktis \\
\hline Pembelajaran 2 (Senin) & 3.7 & 3,7 & 3,7 & Praktis \\
\hline Pembelajaran 3 (Senin) & 3,9 & 3,9 & 3,9 & Praktis \\
\hline \multicolumn{3}{|c|}{ Tingkat Kepraktisan Keterlaksanaan RPP } & $\mathbf{3 , 7 2}$ & Praktis \\
\hline
\end{tabular}

Berdasarkan tabel di atas dapat dinyatakan bahwa keterlaksanaan RPS berada pada kategori praktis pada rentang 3,5-4,0. Hasil rata-rata keterlaksanaan RPS tersebut, secara umum keterlaksanaan pembelajaran metode penelitian berbasis pembelajaran Riset di semester V PGMI sudah terlaksana sesuai rencana.

Dalam hal ini, dapat diketahui bahwa RPS yang dikembangkan dapat dengan mudah dilaksanakan oleh dosen, artinya RPS yang dikembangkan praktis. Menurut Akker dan Plomp (Vila, 2009) bahwa RPS dapat dikatakan praktis, jika dosen dapat menggunakan RPS tersebut untuk melaksanakan pembelajaran secara logis dan berkesinambungan, tanpa banyak masalah. Dengan demikian, RPS berbasis pembelajaran riset yang telah dikembangkan dapat digunakan sebagai contoh pada jurusan lain yang memerlukannya.

\section{Hasil Angket Praktikalitas untuk Dosen}

Angket respon dosen diberikan untuk mengetahui pendapat dosen terhadap RPS yang telah disusun. Analisis data yang diperoleh dari masing-masing angket respon dosen terhadap praktikalitas dosen dapat dilihat tabel di bawah ini:

Tabel 2. Hasil Analisis Angket Respons Dosen

\begin{tabular}{lll}
\hline No. & \multicolumn{1}{c}{ Aspek yang Dinilai } & Skor \\
\hline 1. & Bahasa yang digunakan pada RPS sesuai dengan EYD & 3 \\
2. & Penyajian kalimat mudah dipahami oleh dosen & 3 \\
3. & Kejelasan bahasa yang digunakan sehingga tidak menimbulkan penafsiran ganda & 4 \\
4. & Petunjuk pada RPS memudahkan dosen untuk menyampaikan maksud dan tujuan berbagai kegiatan & \\
& kepada mahasiswa & 4 \\
5. & RPS memudahkan dosen untuk mengajarkan materi pada siswa. \\
6. & Langkah-langkah dalam RPS sesuai alokasi waktu yang tersedia \\
7. & Metode pembelajaran yang digunakan sesuai dengan materi yang disampaikan & 4
\end{tabular}


8. Ketepatan Format RPS

9. RPS memudahkan dosen untuk menarik minat mahasiswa dalam pembelajaran

10 RPS ini dapat dijadikan sebagai salah satu sumber data untuk penilaian proses pembelajaran

Skor yang Diperoleh

Skor Maksimum

Persentase Kepraktisan

Berdasarkan tabel di atas dapat dilihat bahwa persentase rata- rata penilaian terhadap dosen dalam penggunaan RPS berbasis pembelajaran riset di semester V PGMI berada pada kategori praktis yaitu pada rentang 80\%-90\%. Artinya RPS yang dikembangkan telah memiliki kepraktisan baik dari penyajian maupun penggunaannya. Dapat disimpulkan bahwa praktikalitas RPS berbasis pembelajaran riset berdasarkan angket respon guru dikategorikan praktis.

\section{SIMPULAN}

Penelitian ini merupakan penelitian pengembangan yang menghasilkan Rencana Pembelajaran Semester Terintegrasi Research Based Learning. Berdasarkan hasil pengembangan dan ujicoba Rencana Pembelajaran Semester Terintegrasi Research Based Learning dalam pembelajaran yang telah dilakukan, diperoleh simpulan sebagai berikut:

1. Proses pengembangan Rencana Pembelajaran Semester Terintegrasi Research Based Learning di semester V PGMI dilakukan dengan tahap pendefinisian, perancangan, pengembangan, dan penyebaran. Dapat dijelaskan sebagai berikut : 1) tahap pendefinisan adalah melakukan analisis RPS, analisis kebutuhan dan analisis karakteristik mahasiswa. , 2) tahap perancangan dilakukan dengan merancang bentuk produk Rencana Pembelajaran Semester Terintegrasi Research Based Learning , 3) tahap pengembangan dilakukan dengan uji validasi RPS oleh validator.

2. Telah dihasilkan Rencana Pembelajaran Semester Terintegrasi Research Based Learning di semester V PGMI yang valid dan praktis. Hal ini dapat dilihat berdasarkan hasil validasi RPS oleh validator ahli dan praktisi pendidikan yang telah dilaksanakan, yang dikembangkan memperoleh skor rat-rata yaitu 3,9 dengan kategori sangat valid. Hal ini memberikan gambaran bahwa RPS yang dikembangkan telah valid dan dapat digunakan dalam pembelajaran. Praktikalitas RPS diketahui dari hasil pengamatan keterlaksanaan pembelajaran dengan rata-rata $93,3 \%$ kategori sangat praktis, angket respons dosen rata-rata yaitu $90 \%$ dengan kategori praktis.

\section{DAFTAR PUSTAKA}

Anka Monalisa,Lioni, (2014). Pengembangan Perangkat Pembelajaran Mata Kuliah Teori Bilangan Program Studi Pendidikan Matematika
Berdasarkan Kurikulum Kerangka Kualifikasi Nasional Indonesia (KKNI), Jurnal Pancaran, Volume 5, Nomor 4,

Cristy, Kartika, (2014). Pembelajaran Berbasis Riset dengan Pendekatan Saintifik dalam Peningkatan Keterampilan IPA bagi Siswa SD, (disampaikan dalam Seminar Nasional XI Pendidikan Biologi FKIP UNS

Dahlan, Desi. (2012). "Pengembangan Perangkat Pembelajaran Biologi Berbasis Quantum Learning pada Materi Sistem Pencernaan untuk Sekolah Menengah Atas". Tesis Tidak Diterbitkan. Padang: Universitas Negeri Padang.

Diah Tri Widayati, (2010). Pedoman Umum Pembelajaran Berbasis Riset(PUPBR), Yogyakartaa: UGM

Gray, (2019). Educational Research : Competencies for Analysis and Applications( 9 th ed). New Jersey: Pearson EducationInc,

Menteri Riset, Teknologi, Dan Pendidikan Tinggi Republik Indonesia. (2015), Desember 28). Tentang Standar Nasional Pendidikan Tinggi. Peraturan Menteri Riset, Teknologi, Dan Pendidikan Tinggi Republik Indonesia Nomor 44. Jakarta, DKI, Indonesia: Kemenristekdikti.

Mulyatiningsih, E. (2012) Metode Penelitian Terapan Bidang Pendidikan. Bandung: Penerbit Alfabeta

Panduan Penyusunan Kurikulum Pendidikan Tinggi (2016), Direktorat Pembelajaran

KemenristekDikti

Paristiyanti Nurwardani, (2016). Panduan Penyusunan Kurikulum Perguruan Tinggi, Jakarta:Ristekdikti

Purwanto, Ngalim. (2006). Prinsip-Prinsip dan Teknik Evaluasi Pembelajaran. Bandung: Remaja Rosdakarya.

Riduwan dan Sunarto. (2007). Pengantar Statistik untuk Penelitian: Pendidikan, Sosial, Komunikasi, Ekonomi, dan Bisnis. Bandung: Alfabeta.

Sugirin, (2015) Kajian Perangkat Pembelajaran sebagai Penentu Ketercapaian Kompetensi Ahli Pendidikan Bahasa sesuai Kerangka Kualifikasi Nasional Indonesia, Laporan Hasil Penelitian UNY

Sugiyono. (2011). Metode Penelitian Kuantitatif, Kualitatif, dan R\&D, Bandung: Alfabeta, 2011

Trianto. (2011). Pengantar Penelitian Pendidikan Bagi Pengembangan Profesi Pendidikan dan Tenaga Kependidikan Jakarta: Kencana Prenada Media Group 
Umil Muhsinin dan Kiki Fatmawati, Validitas dan Praktikalitas Rencana Pembelajaran Semester (RPS) Terintegrasi Research Based Learning

Tri Widayati,Diah. (2010). Pedoman Umum Pembelajaran Berbasis Riset(PUPBR), Yogyakartaa: UGM

Undiksha. (2016). Panduan Pengembangan Perangkat Pembelajaran Kurikulum Undiksha 2016 Silabus RPS dan Kontrak Perkuliahan. Singajara: LPPPM Undiksha 